\title{
The effect of folic acid and iron in the prevention of nutritional anaemias in pregnancy in Nigeria
}

\author{
By 'BOLA O. A. OSIFO \\ Department of Food Science and Applied Nutrition, \\ University of Ibadan, Ibadan, Nigeria \\ (Received 23 October 1969-Accepted 26 fanuary 1970)
}

\begin{abstract}
I. Fifty-two pregnant women in a village were divided into three groups, A, B and C, and were given the following supplements: $A$, iron in the form of $200 \mathrm{mg}$ ferrous sulphate daily; $\mathrm{B}, \mathrm{Fe}$ (as group A) and $5 \mathrm{mg}$ of folic acid daily; C, Fe and folic acid (as group B) plus an antimalarial drug.

2. Blood samples were collected each week and assessed for haemoglobin and haematocrit values.

3. Dietary intakes of $\mathrm{Fe}$ and folic acid were calculated for both pregnant and non-pregnant women. Results revealed that $\mathrm{Fe}$ intake was adequate and $\mathrm{Fe}$ deficiency not common. The supplement of $\mathrm{Fe}$ increased the haemoglobin levels.

4. Folic acid intake was low and intake probably fluctuated during the year because of seasonal changes in the dietary folic acid.

5. About $28 \%$ of patients, during their first attendance, had haematocrit values below normal. Folic acid supplements increased these values.
\end{abstract}

Nutritional anaemias, which have always been considered as one of the common health problems in the developing countries, become more marked under the physiological stress of pregnancy. Woodruff (I95I) reported that the anaemia of pregnancy in Nigeria was mostly due to protein deficiency, as iron, yeast extract, folic acid and cyanocobalamin all failed to produce a reticulocyte response. Watson-Williams (I959) reported that Fe deficiency during pregnancy was relatively rare in Western Nigeria and Fullerton \& Watson-Williams (I962) concluded that the severest anaemias were almost always megaloblastic. Other workers (Lawson, I962; Fullerton \& Turner, 1962 ; Fleming \& Elliott, 1964 ; Ojo, 1965) reported that the two important factors responsible for anaemias in pregnancy were haemolysis related to malarial infection and folate deficiency. Despite these recent findings, an Fe supplement in the form of ferrous sulphate is a routine antenatal drug in hospitals and health centres throughout Nigeria. This study set out to investigate the major cause of nutritional anaemia during pregnancy in a Nigerian village and to find whether it is necessary to continue with antenatal Fe supplements.

\section{EXPERIMENTAL}

The village. The study was made at the village of Osegere, 15 miles north-east of Ibadan (the capital of Western State), with a population of about 1500.

Subjects. Fifty-two pregnant women between 18 and 40 years were involved in the study. These women lived in the village and attended the health centre there, which was run by community nurses for their routine antenatal care. The subjects ate their usual diet and received little education in nutrition. The women chosen were those with 
normal pregnancy. Any complicated case was dropped from the survey and referred to the Ibadan University teaching hospital. The women were divided into three groups based on the day convenient for them to attend the weekly clinic. They all came under this study during their second trimester, ranging from the $1_{5}$ th week of gestation to the 22nd week. Group A attended the clinic on Mondays, group B on Wednesdays and group $\mathrm{C}$ on Fridays.

Table I. Haematological values for pregnant women in Nigeria (Interdepartmental Committee on Nutrition for National Defence, 1965)

$\begin{array}{lcc}\text { Category* } & \begin{array}{c}\text { Haemoglobin } \\ \text { (g/roo ml blood) }\end{array} & \begin{array}{c}\text { Packed cell } \\ \text { volume }(\%)\end{array} \\ \text { Deficient } & 9 \cdot 0 & 30 \cdot 0 \\ \text { Low } & 9 \cdot 0-9.9 & 30 \cdot 0-34.9 \\ \text { Acceptable } & 10 \cdot 0-12.9 & 35 \cdot 0-37.9 \\ \text { High } & 13.0 & 38 \cdot 0\end{array}$

* 'Deficient' signifies a condition in which signs of anaemia are well marked, 'low' one in which anaemia can be regarded as normally present, 'acceptable' one in which anaemia might occur, and 'high' one in which there is no biochemical evidence of anaemia.

Supplements. The patients in group A received Fe as ferrous sulphate $(200 \mathrm{mg})$ three times a day. Group B patients received Fe (as in group A) and, in addition, folic acid (a $5 \mathrm{mg}$ tablet of pteroylglutamic acid daily). Group $\mathrm{C}$ patients were given the supplements of $\mathrm{Fe}$ and folic acid as in group $\mathrm{B}$ plus an antimalarial drug. At first, they were given $800 \mathrm{mg}$ of chloroquine sulphate (Nivaquine; May \& Baker Ltd, Dagenham, Essex) to clear any clinical signs of malaria and they were then given $25 \mathrm{mg}$ of pyrimethamine (Daraprim; Burroughs Wellcome, Io Lancaster Onike Road, Yaba, Lagos, Nigeria) weekly to prevent the recurrence. All these supplements were given from the Ist day of attendance until delivery.

Biochemical methods. At every attendance of the patients, blood samples were taken from the left thumb. Haemoglobin was measured as cyanmethaemoglobin (King \& Wootton, 1956). Haematocrit values were measured in heparinized capillary tubes with the aid of a portable haematocrit centrifuge (Dacie \& Lewis, I963) and they were compared with the values shown in Table $\mathbf{I}$.

Measurement of food intake. Three nutrients were studied: protein, Fe and folic acid. The intake of these nutrients was calculated from the diets (Osifo, I970) of the pregnant women by the use of a recall method during their interview. The same recall method was used for a random sampling of thirty non-pregnant women in the same village.

\section{RESULTS}

Table 2 shows the average haemoglobin levels of the three groups from their Ist day of attendance to the time of delivery. There was only one patient whose haemoglobin level was in the 'deficient' category at first attendance. All haemoglobin levels increased with supplementation with $\mathrm{Fe}$ as the pregnancy progressed. Fig. I shows the 
percentage distribution of patients under various categories of haemoglobin level from first attendance to third trimester.

Table 3 shows that the average haematocrit values of groups $B$ and $C$ increased during pregnancy, compared with those of group A, which did not receive the folic acid supplement. Fig. 2 shows the percentage distribution of patients under the various categories of haematocrit value.

Table 2. Average haemoglobin levels ( $\mathrm{g} / \mathrm{100} \mathrm{ml}$ blood) of pregnant women in Nigeria

\begin{tabular}{|c|c|c|c|c|c|c|}
\hline & \multicolumn{2}{|c|}{ Group A } & \multicolumn{2}{|c|}{ Group B } & \multicolumn{2}{|c|}{ Group C } \\
\hline & Mean & Range & Mean & Range & Mean & Range \\
\hline ince & I2.I (I 8$)$ & $9 \cdot 8-14 \cdot 0$ & I2.2 (I9) & $7 \cdot 6-13 \cdot 6$ & $12 \cdot 3(20)$ & 9 \\
\hline Second trimester & $\mathrm{I} 2 \cdot 9(\mathrm{I} 6)$ & $9 \cdot 7-14 \cdot 2$ & $13.0(17)$ & $9 \cdot 5-14 \cdot 5$ & $13.2(18)$ & II $\cdot 9-14 \cdot 4$ \\
\hline Third trimester & $13 \cdot 1(17)$ & $9 \cdot 4-14 \cdot 4$ & 13.4 (17) & $8 \cdot 4-14.8$ & 1 $3.8(18)$ & $11 \cdot 7-15 \cdot 2$ \\
\hline
\end{tabular}

Figures in parentheses are the numbers of patients examined.

Group A were given an iron supplement, group B iron and folic acid supplements, and group C iron and folic acid supplements and an antimalarial drug.

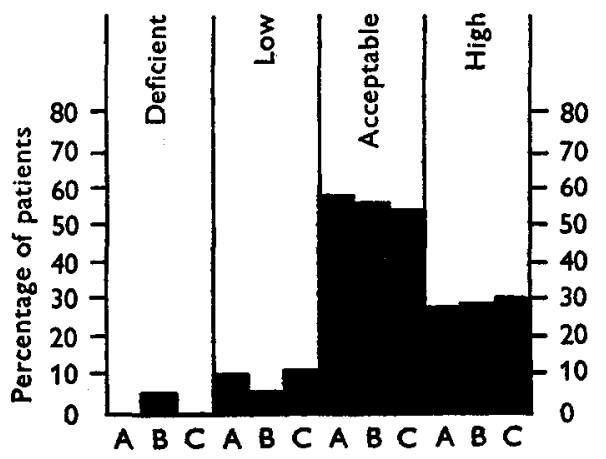

(a)

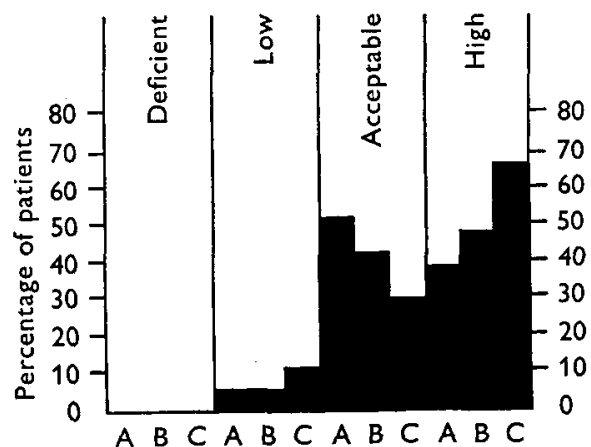

(b)



(c)

Fig. I. Percentage distribution of the three groups (A, B and C) of pregnant Nigerian women among the different categories of haemoglobin level $(a)$ at first attendance, $(b)$ during second trimester and $(c)$ during third trimester. A, group given iron supplement; B, group given $\mathrm{Fe}$ and folic acid supplements; C, group given the same supplements as group B plus an antimalarial drug. 
Table 4 shows the average nutrient intake and the recommended allowances for both pregnant and non-pregnant women; Table 5 shows the average intake of these nutrients during the dry season of the year. The only nutrient that seemed to fluctuate during the year was folic acid.

Table 3. Average haematocrit values (packed cell volume \%) of pregnant women in Nigeria

First attendance

Second trimester

Third trimester

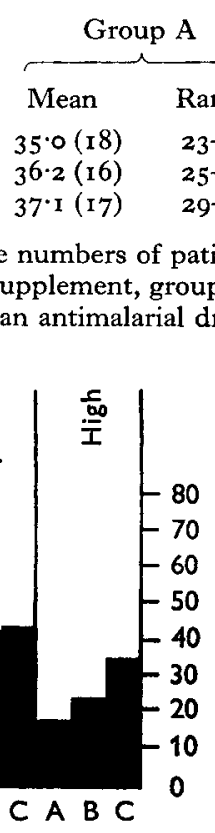

(a)

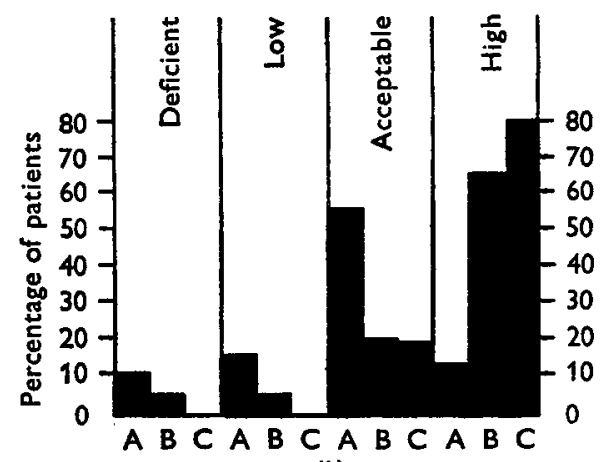

(b)

\begin{tabular}{|c|c|}
\hline \multicolumn{2}{|c|}{ Group C } \\
\hline Mean & Range \\
\hline $36 \cdot 6(20)$ & $30-43$ \\
\hline $3^{8 \cdot 5}$ (18) & $35-42$ \\
\hline $4 I \cdot 3(18)$ & 36 \\
\hline
\end{tabular}

Figures in parentheses are the numbers of patients examined.

Group $\mathrm{A}$ were given an iron supplement, group $\mathrm{B}$ iron and folic acid supplements, and group $\mathrm{C}$ iron and folic acid supplements and an antimalarial drug.
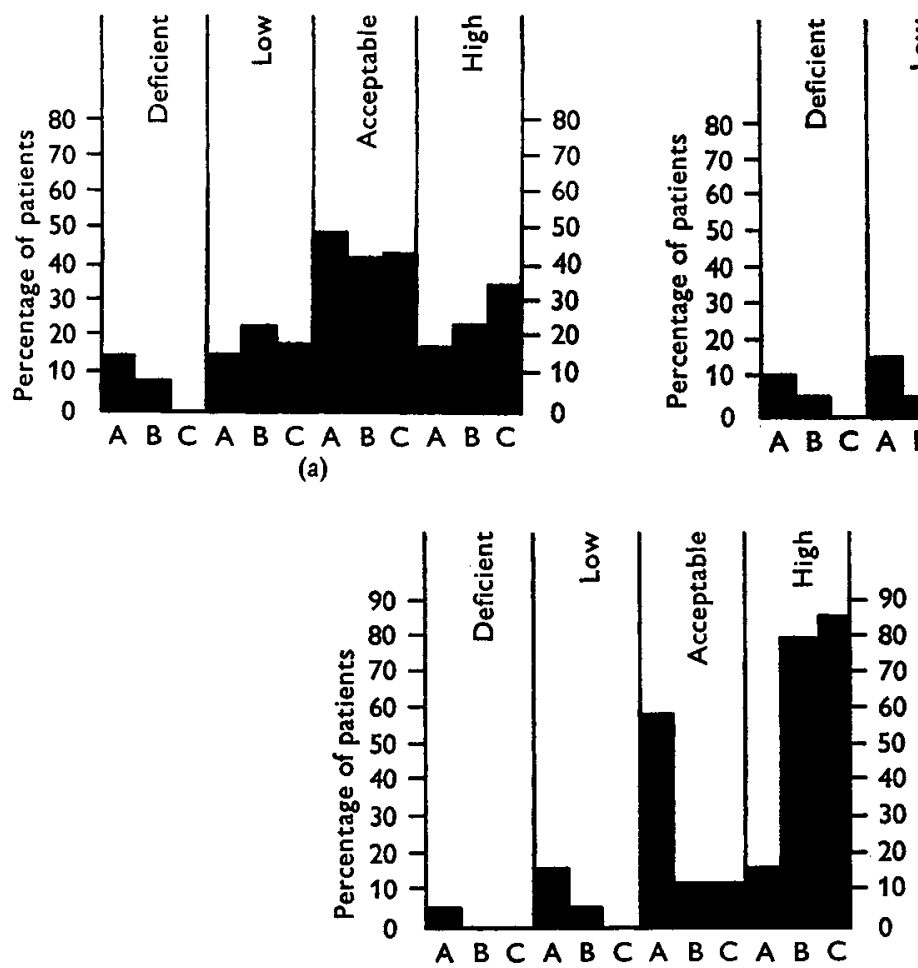

(c)

Fig. 2. Percentage distribution of the three groups (A, B and C) of pregnant Nigerian women among the different categories of haematocrit value (packed cell volume \%) (a) at first attendance, $(b)$ during second trimester and $(c)$ during third trimester. A, group given iron supplement; $\mathrm{B}$, group given $\mathrm{Fe}$ and folic acid supplements; $\mathrm{C}$, group given the same supplements as group $\mathrm{B}$ plus an antimalarial drug. 
Table 4. Average daily intakes and recommended allowances of specific nutrients for Nigerian women

\begin{tabular}{|c|c|c|c|c|}
\hline \multirow[b]{2}{*}{ Nutrient } & \multicolumn{2}{|c|}{ Non-pregnant women } & \multicolumn{2}{|c|}{ Pregnant women } \\
\hline & Intake & $\begin{array}{l}\text { Recommended } \\
(1964)^{*}\end{array}$ & Intake & $\underset{(1964)^{*}}{\text { Recommended }}$ \\
\hline$(\mathrm{kcal})$ & 2111 & 2300 & 2349 & 2500 \\
\hline Protein (g) & 42 & 60 & 45 & 80 \\
\hline Iron (mg) & 16 & Io & $\begin{array}{l}75 \\
19\end{array}$ & 18 \\
\hline Folic acid $(\mu \mathrm{g})$ & 93 & $\rightarrow$ & 118 & -+ \\
\hline
\end{tabular}

* From the report of the Health Education Seminar, held in Nigeria in 1964.

$\dagger$ So far, no accurate estimate of the daily requirement for folic acid has been made, but it is generally accepted that an average diet that will maintain good folic acid nutrition should contain $500 \mu \mathrm{g}$ daily.

\section{Table 5. Average daily intake of specific nutrients by Nigerian} women in the dry season

$\begin{array}{lcccc} & \begin{array}{c}\text { Calories } \\ (\mathrm{kcal})\end{array} & \begin{array}{c}\text { Protein } \\ (\mathrm{g})\end{array} & \begin{array}{c}\text { Iron } \\ (\mathrm{mg})\end{array} & \begin{array}{c}\text { Folic acid } \\ (\mu \mathrm{g})\end{array} \\ \text { Pregnant women } & 2100 & 38 & 16 & 68 \\ \text { Non-pregnant women } & \mathrm{I} 827 & 32 & 14 & 60\end{array}$

\section{DISCUSSION}

At their first attendance, only $2 \%$ of patients had a deficient haemoglobin level, while ro \% had low haemoglobin levels. This finding supports the Watson-Williams (1959) report that Fe deficiency in western Nigeria is not common. From Table 4 it can be seen that the $\mathrm{Fe}$ intake was adequate, and this is one of the reasons for the low incidence of Fe-deficiency anaemia. Another possible reason is that there is a low incidence of heavy hookworm infestation among Nigerian women (Gilles, 1965). It can be concluded that the $\mathrm{Fe}$ intake in the village would support normal haemoglobin levels and low or deficient levels only arise during the stress of pregnancy. Fig. I shows that in group $\mathrm{A}$ there was an increase generally in haemoglobin levels when $\mathrm{Fe}$ was given. At the third trimester, $39 \%$ of the patients had high haemoglobin levels compared with only $29 \%$ at the first attendance.

In group B, as shown in Fig. I, there was an increase in haemoglobin levels when $\mathrm{Fe}$ and folic acid were given. At the third trimester, $68 \%$ of them had high haemoglobin levels compared with $30 \%$ at the first attendance. Group C also showed a marked rise in haemoglobin levels, $75 \%$ having high haemoglobin levels during the third trimester compared with $32 \%$ at the first attendance.

About $8 \%$ of the fifty-two patients had deficient haematocrit values on first attendance compared with $2 \%$ with deficient haemoglobin levels. About $20 \%$ had low haematocrit values. This means $28 \%$ of the study group started with non-acceptable haematocrit values. There was no rise in haematocrit values in group A despite the $\mathrm{Fe}$ supplement. Only $17 \%$ of group A had high haematocrit values during the third trimester compared with $18 \%$ during the first attendance. The only improvement was that the percentage of those with deficient haematocrit values dropped from 16 to $6 \%$ 
at the third trimester. Group B showed an outstanding increase in their haematocrit values, the percentage of patients with high haematocrit values rising from $24 \%$ at first attendance to $81 \%$ during the third trimester. In this group, there was no patient with a deficient haematocrit value during the third trimester. The value of the folic acid supplement seems clear. From Table 4 it can be seen that normal dietary folic acid was low. Indeed, it was probably lower during the dry season when vegetables become rare and expensive and yams, which are good sources of folic acid, are dried up.

Group $\mathrm{C}$ also showed an outstanding increase in their haematocrit values, $87 \%$ of the patients having high values during the third trimester compared with $35 \%$ during the first attendance. The value of the folic acid supplement is again clear. The differences between group $\mathrm{B}$ and group $\mathrm{C}$ are not marked enough for any strong conclusion to be drawn as to the value of antimalarial drugs. Moreover, the numbers of patients in each group are not large enough for statistical analysis. This is a preliminary report of work still going on and, in another year, a better evaluation of the effect of antimalarial drugs and seasonal variations may emerge.

This study shows that in Nigeria Fe deficiency anaemia is not common in pregnancy; but it should not be regarded as rare, since the usual intake of Fe might not be able to meet the physiological demands during this period. Fe supplements should be encouraged, especially during the third trimester. Folic acid intake seems low and, with drastic fluctuations during the year due to seasonal changes, a folic acid supplement is essential during pregnancy. It should be given as soon as the patients start attending the clinic, usually during the second trimester.

Professional advice on the prescription of drugs in this study was given by $\operatorname{Dr} A$. Omololu, the head of the Department. The author is highly indebted to him. The author is also grateful to Professor J. P. de V. Hendrickse, head of the Department of Gynaecology and Obstetrics in the University for taking care of the patients who needed special obstetric care.

\section{REFERENCES}

Dacie, I. V. \& Lewis, S. M. (1963). Practical Haematology 3 rd ed. London: J. and A. Churchill Ltd. Fleming, A. F. \& Elliott, B. A. (1964). Br. med. F. ii, rio8.

Fullerton, W. T. \& Turner, A. G. (I962). Lancet i, 75 .

Fullerton, W. T. \& Watson-Williams, E. J. (1962). F. Obstet. Gynaec. Br. Commonw. 69, 729.

Gilles, H. M. (1965). Akufo. Ibadan: University of Ibadan Press.

Interdepartmental Committee on Nutrition for National Defence (1965). Nutrition Survey in Federal Republic of Nigeria. Washington, DC: U.S. Department of Health.

King, E. J. \& Wootton, I. D.P. (1956). Micro-analysis in Medical Biochemistry 3rd ed. London: J. and A. Churchill Ltd.

Lawson, J. B. (1962). Ghana med. F. r, 3 I.

Ojo, O. A. (1965). I. Nigerian med. Ass. 1, 224.

Osifo, 'B. O. A. (1970). Br. F. Nutr. 24,683.

Watson-Williams, E. J. (1959). Ann. Rep. Dep. Path. University College, Ibadan.

Woodruff, A. W. (195I). Br. med. $\mathscr{~}$. ii, I4I 5. 